\title{
The relationship between prisoners' academic self-efficacy and participation in educa- tion, previous convictions, sentence length, and portion of sentence served
}

\author{
by BEATE BUANES ROTH, ARVE ASBJØRNSEN \& TERJE MANGER \\ University of Bergen
}

\begin{abstract}
Prison education is an important aspect of adult education. This study investigated current participation in prison education, as well as previous convictions, sentence length, and the portion of sentence served as predictors of academic self-efficacy. Survey data derived from prisoners in all Norwegian prisons provided the empirical evidence for the analyses. A principal component analysis of a 40-item academic self-efficacy questionnaire revealed self-efficacy components in literacy, mathematics, information and communications technology (ICT), and self-regulated learning. Educational participation had a positive influence on self-efficacy in both mathematics and self-regulated learning. Participants who reported no previous convictions scored higher than others on self-efficacy in mathematics, self-regulated learning, and ICT. Furthermore, the results showed that perceived efficacy in ICT decreased with longer sentence length. Portion of sentence served was not significantly related to any of the four self-efficacy components. The findings are discussed with reference to a need for mastery experiences in prison and implications for policy and practice.
\end{abstract}

Key words: Prison education; academic self-efficacy; sentence length; adult education

\section{Introduction}

The aim of this study was to examine Norwegian prisoners' academic self-efficacy, and ascertain the influence that current participation in education, previous convictions, sentence length, and portion of sentence served had on their academic efficacy beliefs. Prisoners constitute a vulnerable group and their academic self-efficacy may be influenced by previous negative experiences in school, which is a common feature among prisoners (Council of Europe, 1990). Likewise, factors related to their sentence, such as sentence length and portion of sentence served may also have an impact on their academic self-efficacy. However, prisoners have the same right to education as other citizens (e.g., Council of Europe, 2006) and participation in education and other aspects of incarceration may also improve their efficacy beliefs.

\section{Self-efficacy in academic settings}

Bandura (1997) defined self-efficacy as the individual's perceived ability to succeed at or accomplish certain tasks. Academic self-efficacy is thus central to success in school or education and can serve as an explanatory factor for why people's achievement may differ even though they have similar knowledge and skills. The concept of self-efficacy constitutes a conceptual structure grounded in the broader framework of Bandura's social cognitive theory. In line with his definition, self-efficacy is a question of self-perception rather than the actual level of an individual's efficiency (Bandura, 1986, 1997). Self-efficacy concerns the answer to the question, "Can I do this task in this situation?" (Linnenbrink \& Pintrich, 2003, p. 120). Someone who has a high sense of self-efficacy in one area is likely to attempt a new task, whereas a person with low self-efficacy is more likely to try to avoid it. Because self-efficacy is defined as individuals' beliefs about their capabilities to produce given attainments (Bandura, 1997), it is likely that they bring with them to any challenging situation, such as a school, certain characteristics that are related to their self-efficacy. Perceived self-efficacy takes into account the influence of both external physical and social complexities and internal cognitive processes. This is concretized through Bandura's (1986) proposed origins of efficacy beliefs, which 
include mastery experiences, vicarious experiences (role models), social or verbal persuasion, and self-interpretation of physical/emotional arousal. The most reliable source for appraising one's self-efficacy is that of prior mastery experiences (Bandura, 1986), which means that success enhances efficacy beliefs, while failure diminishes them. The way in which individuals interpret previous attainments and environmental conditions influences their self-beliefs, which in turn inform and alter their subsequent actions and interactions with the environment (Pajares, 1996; Schunk \& Meece, 2006).

Self-efficacy is originally construed to be task or domain specific (Bandura, 2006), and has displayed a potential for extensive application in the context of educational motivation and learning. When applied to academic settings, the common term is academic self-efficacy - students' beliefs concerning their ability to perform academically related tasks (Bong \& Skaalvik, 2003), such as solving a math problem, reading a book, writing words correctly, communicating via email or finishing schoolwork on time. The latter case refers to self-efficacy for self-regulated learning, which is another facet of academic self-efficacy, along with efficacy beliefs for subject-specific tasks. Self-efficacy for self-regulated learning has been commonly measured in educational self-efficacy research as it applies to functioning across academic subjects (Klassen \& Usher, 2010).

Students' self-efficacy beliefs influence their performance in several ways. It is a consistent predictor of their pursued course of action, coping behaviors (i.e., effort, persistence, and resilience), and ultimately, their achievements (Bandura, 1997). According to Pajares (2002), the beliefs students develop about their academic capabilities help determine what they do with the knowledge and skills they have learned: "Consequently, their academic performances are, in part, the result of what they come to believe they have accomplished and can accomplish" (p. 116).

\section{Self-efficacy in a prison context}

Participation in education during incarceration can play an important role in the daily life of many prisoners and has significant consequences for resettlement on release (e.g., Nally, Lockwood, Ho, \& Knutson, 2014). The idea of "prison as a positive environment for learning" (European Commission, 2011, p. 4) is wide-reaching in a European context. It is grounded in the assumption that education and training should be integrated into all aspects of the prison regime, but the application of the concept appears to vary considerably from country to country. Prisoners belong to a vulnerable group, and without skills and knowledge, there is an increased risk of exclusion from the ordinary labor market, of poverty, debt, substance abuse, and the absence of an ordinary social network. From a socio-economic point of view, low educational achievement, which is a common trait among prisoners (Eikeland, Manger, \& Asbjørnsen, 2013), results in fewer opportunities in the labor market. Because of this, individuals who have served time in prison are likely to be dependent on welfare benefits and thereby increase the burden on society (e.g., Lochner \& Moretti, 2004; Palmer, 2012). In a personal and social perspective, prisoners who participate in education reduce the risk of recidivism and increase their post-release employment opportunities (Davis, Bozick, Steele, Saunders, \& Miles, 2013; Kim \& Clark, 2013).

A considerable amount of research across various levels of education and at different ability levels features self-efficacy as a predictor and mediator of students' achievement, motivation and learning (Dinther, Dochy, \& Segers, 2011; Pajares, 2002; Schunk \& Mullen, 2012; Zimmerman, 2000). However, scant research has explored prisoners' beliefs in their academic capabilities. Prisoners, like other members of society, form their self-efficacy by interpreting information from Bandura's proposed four sources (mastery experiences, vicarious experiences, social/verbal persuasion, and self-interpretation of physical/emotional arousal), of which the most powerful one, for prisoners as well, is the interpreted result of one's previous performance, or mastery experiences. The academic self-efficacy of the majority of prisoners has probably been influenced by a lack of mastery experiences but also a lack of modeling effects, minor persuasion from others, and physical symptoms that have been interpreted as signs of lacking ability. Thus, one should assume that an enhanced level of education along with mastery experiences from participation in educational activities in prison should increase their academic self-efficacy. The modeling effect may be of special importance in a prison context. When another prisoner, who the learner identifies with, performs well in school, the learner's efficacy can be enhanced. The more closely the prisoner identifies with the model, the greater the impact on efficacy beliefs.

A previous study among a selected group of prisoners in Norway revealed that educational level was a 
significant factor for both reading and writing self-efficacy (Jones, Varberg, Manger, Eikeland, \& Asbjørnsen, 2012), but in reviewing the literature (using ERIC, psychINFO, and Google Scholar), we found no studies that specifically examined the relationship between participation in prison education and academic self-efficacy. However, in a pre/post study on general self-efficacy among prisoner students and college students who jointly participated in three different prison-based Inside-Out courses, Allred, Harrison, and O'Connell (2013) found that incarcerated participants (insiders) reported significantly lower levels of self-efficacy at Time 1 and an increase at Time 2. In contrast, college students (outsiders) did not experience any shift in level of general self-efficacy across time. Also, an enquiry by Ross (2009) aiming to examine the benefits of post-secondary correctional education (PSCE) among six selected in-prison college programs in New York State and across the United States revealed that participation in prison education can have a significant psychological impact on prisoners. The impact included an increase in perceived self-efficacy towards general functional self-management abilities as described by several interviewed prisoners and previously incarcerated individuals in the study.

Participation in prison programming, including education, is regarded as a way of adapting to prison life (Dhami, Ayton, \& Loewenstein, 2007), and studies have revealed that prison sentence variables, such as sentence length and portion of sentence served, are related to both participation in education and educational motives. With increasing sentence length, prisoners are found more likely to participate in education and tend to value education for reasons that can be related to future planning and competence building (Jones, Manger, Eikeland, \& Asbjørnsen, 2013; Roth \& Manger, 2014). Further, prisoners are found to participate to a greater extent with more time served of their current sentence (Jackson \& Innes, 2000; Rose \& Rose, 2014). However, a search of the literature (ERIC, psychINFO, Google Scholar) revealed no studies examining the relationship between sentence variables and academic self-efficacy. Based on the literature (Asbjørnsen, Eikeland, \& Manger, 2015; Jones et al., 2012; LaRose, Gregg, Strover, Straubhaar, \& Carpenter, 2007; Manger, Eikeland, \& Asbjørnsen, 2013; Schunk \& Pajares, 2002), gender, age, educational level, and educational challenges such as dyslexia and ADHD need to be controlled for when examining the relationship between participation in education and other prison programs, educational motives and academic self-efficacy, which will be examined in the present study. Previous convictions can also be considered as a control variable because it belongs to the story prisoners bring into the prison. In the present study, however, we will treat it as a sentence variable related to sentence length and portion of sentence served.

\section{Prison education in Norway}

In Norway, prisoners are required to participate in activities during penalty implementation, and education, prison work or programs (e.g., aggression management) are parts of the mandatory activities. Aside from the restrictions naturally accompanying deprivation, convicts have the same right to services and amenities, as well as the same obligations and responsibilities, as the population at large. The law prescribes ten years of primary or lower secondary education (age 13-16) and three to five years of upper secondary education. The upper secondary education is not an obligation, but rather a right, and has three branches (general, mercantile, and vocational). Prisons in Norway have adopted the so-called import model for delivery of services to the prisoners (Christie, 1970). It therefore follows that the regular school systems are to supply educational services in prison. The import model, or administrative collaboration, is working with the intention of establishing a learning environment that is as normal and open as possible within a closed system. This is also a way of making other institutions aware of their responsibilities, by indicating that they too have an obligation to assist in the return of prisoners to the community (County Governor of Hordaland, 2005). The Education Act of Norway recognizes the general right to basic schooling, and the right of those who have completed mandatory schooling (age 6 or 7 to 16) to three years of upper secondary education (1998, § 2-1, § 3-1). Also prisoners are guaranteed these rights. From 2006, there has been a steady increase in educational participation among incarcerated in Norway, ranging from a participation rate of one out of three to more than half of the prisoners in 2012 (Eikeland, Manger, \& Asbjørnsen, 2009; Eikeland et al., 2013). Consequently, education has become the most important prison activity. However, more knowledge is needed on how this relates to various aspects of the prisoners' academic self-efficacy.

Research problem: The aim of the study was to examine how various aspects of the prisoners' sentence re- 
late to their academic self-efficacy. Thus, we included variables that reflect important aspects of the sentence such as participation in education, sentence length, portion of sentence served, and previous convictions. The research problem is: How does participation in prison education, previous convictions, sentence length, and portion of sentence served influence prisoners' academic self-efficacy when controlled for age, gender, educational level, diagnosed reading and writing difficulties/dyslexia and ADHD? Due to a lack of research on the relationship between the described prison variables and academic self-efficacy, we may expect several possible outcomes. However, in line with previous literature, we assume that several aspects of academic self-efficacy will increase with participation in prison education, especially because such participation may increase mastery experiences. Based on the studies reviewed for this project, one could also assume that previous convictions contribute to low academic self-efficacy, but that effects of sentence length and portion of sentence served may be difficult to predict. Possible negative effects may be balanced by opportunities to use the sentence to acquire information from important sources of academic self-efficacy.

\section{Method}

\section{Participants}

The present study derives from a population-based survey of all prisoners with Norwegian citizenship over the age of 18 in Norwegian prisons (in principle, young people below the age of 18 are not incarcerated in Norway). The survey questionnaire was administered during a one-week period in October 2012. The Norwegian Ministry of Justice and Public Security reported 2,439 prisoners having Norwegian citizenship at the time of data collection (Jan Erik Sandlie, personal communication, October 24, 2012). The participation rate of those who received the questionnaire was 52.3 per cent $(\mathrm{N}=1276)$, of whom 94.2 percent were male and 5.8 percent were female. This sample was close to the gender distribution in the actual prison population, being 94.7 and 5.3 percent, respectively (Eikeland et al., 2013). The mean age of the respondents was 36 years $(\mathrm{SD}=11.6)$. At time of the commitment, about half of the prisoners had mandatory school as the highest level of education they had attained. A total of 27.4 percent of the prisoners had only completed upper-secondary school or vocational education, compared to 42.0 percent of the population in Norway in 2012 (Statistics Norway, June 18,2013), whereas twelve percent reported completion at the university or university college level, compared to 29.8 per cent of the population (Statistics Norway, June 18, 2013). The percentage of prisoners with no educational achievement was 7.2. About half the participants were sentenced to a prison term of up to 12 months, and 40.5 percent had served less than one-third of their sentence. Furthermore, 64 percent of the participants had prior convictions, one or more times, and many of them may have been incarcerated for several offences at the same time, which is normal in Norway. As the participants are all Norwegian citizens, we suppose that a great majority of those with prior convictions have been convicted and served their time in Norway, but we do not have specific information about this.

\section{The Questionnaire}

The study is part of a larger study on prisoners' education, work, and skills. A self-report questionnaire was designed and contained a number of questions relating to these topics. A central aspect in the present study was the prisoners' academic self-efficacy, along with actual participation in prison education and different aspects of the prisoners' sentences. Common demographic variables, such as gender, age, and level of education were also requested. Additionally, we collected data on diagnosed reading and writing difficulties/dyslexia and ADHD, which have been shown to influence several aspects of prison life and prison education (Asbjørnsen et al., 2015; Jones et al., 2013).

According to Bandura (2006), "self-efficacy scales must be tailored to activity domains and assess the multifaceted ways in which efficacy beliefs operate within the selected activity domain" (p. 310). Thus, the prisoners' academic self-efficacy was assessed by means of 40 items covering particular tasks in reading, writing, mathematics, ICT, and self-regulated learning. The reading self-efficacy and writing self-efficacy items were originally adapted from Shell, Colvin, and Bruning (1995) and were applied in a previous study among prisoners in Norway (Jones et al., 2012). Reading self-efficacy contained task items (e.g., "read newspapers") and skill items (e.g., "understand the meaning of plural endings, prefixes and suffixes"). Likewise, writing self-efficacy contained task items (e.g., "write down the rules of a game") and skill items (e.g., "use words correctly in singular and plural"). The remaining segments of the scale, which covered mathematics (e.g., 
"solve equations"), ICT (e.g., "send and receive e-mails"), and self-regulated learning (e.g., "make weekly plans for schoolwork", "take notes during a lesson"), were designed by the Bergen Cognition and Learning Group (BCLG), in line with guidelines for constructing self-efficacy scales (Bandura, 2006). The ICT items were partly adapted from a study among lower secondary school students in Norway (Manger, Eikeland, \& Vold, 2009; Vold, 2007). Students use various self-regulatory learning strategies, such as planning and organizing schoolwork, taking notes during lessons and completing the work on time. Thus, some self-efficacy for self-regulated learning items were adapted from Bandura's Children's Self-Efficacy Scale (CSES; Bandura, 2006), while others were constructed by the BCLG. For each of the 40 items, the participants were instructed to rate their level of perceived capability to complete the proposed tasks on an 11-point Likert-type scale ranging from 0 (not at all) to 10 (highly certain I can). Cronbach's $\alpha$ coefficient was measured to 0.97. Current participation in education was indicated with eight response options: "No, I am not taking part in any education/training", "primary/lower secondary school", "first year of upper secondary school", "second year of upper secondary school", "third year of upper secondary school", "vocational education", "university or university college", and "short courses". Aspects of the prisoners' sentences included previous convictions, sentence length, and portion of sentence served. Previous convictions were divided into "yes" and "no" responses. Sentence length was identified through 15 options: "three month or less", "three to six months", "six to twelve month", "one to two years", "two to three years", and so on, up to "more than twelve years". Portion of sentence served was grouped as: "just started", "shorter than a third", "between a third and two-thirds", "over two-thirds", and "practically done".

Furthermore, level of education had eight options: "not completed any education", "primary school/ lower secondary school", "one year of upper secondary school", "two years of upper secondary school", "completed upper secondary school", "vocational college", "individual subjects at a university or university college", and "a degree course at a university or university college". Diagnosed reading and writing difficulties/dyslexia and ADHD both had three response categories: "yes, as a child", "yes, as an adult", and "no, never". Finally, the respondents registered year of birth.

\section{Procedure and ethical consideration}

The Norwegian Ministry of Education has delegated the main responsibility for prison education in Norway to the County Governor of Hordaland, Department of Education. To initiate the study, one representative from this department approached each prison governor and headmaster in charge of prison education and informed them of the study's objectives and procedures. In addition, the information was printed on the front page of the questionnaire. As instructed by the research group, the prison governor or headmaster in charge of education administered the data collection.

The study was authorized by the Norwegian Centre for Research Data, the prison authorities, and the Norwegian Ministry of Justice and Public Security. The procedure and information was also elaborated in collaboration with the Regional Committee for Medical and Health Research Ethics in Health Region 4. At the time of the survey, the prisoners were given clear written information about the study. Assurance of voluntary participation, anonymity and confidentiality, and the right to withdraw at any time during completion of the questionnaire were affirmed. The printed information emphasized that participation or withdrawal would have no effect on their incarceration or treatment and opportunities in the prison. However, in line with the aim of the study, to benefit the Norwegian Ministry of Education's further development of prison education programs, we also informed respondents that a high response rate is important because it will assure that further programs will accommodate the needs of future prisoners. In line with ethical recommendations, prisoners were not provided with incentives, as this would have placed a pressure on them to reply. The prisoners answered almost all of the questions by ticking the box(-es) that best described their situation (the only exception was age). If needed, prison personnel were available to assist the prisoners in reading the questionnaire. The questionnaires were returned without names or numbers linked to names, but were marked with a prison number.

\section{Statistical analyses}

Initial descriptive statistics were used to depict the prison populations' characteristics. To measure the internal consistency of the academic self-efficacy scale, internal consistency reliability testing was applied by 
means of Cronbach's $\alpha$ coefficient. Bivariate and multivariate analyses were conducted, including exploratory factor analysis to identify domains of academic self-efficacy, Pearson's correlation analysis, and multivariate linear regression analyses to assess the influence of prison sentence variables on the potential domains. Independent samples t-tests were performed to evaluate group mean differences in academic self-efficacy between (a) prison educational participants and (b) non-participants. Effect sizes for statistical differences were calculated by means of Cohen's d (Cohen, 1988). All statistical analyses were performed using the statistical package IBM SPSS Statistics, version 23.

\section{Results}

At face value, the academic self-efficacy scale provides a measure of five distinct domains of self-efficacy, namely reading, writing, mathematics, ICT, and self-regulated learning. However, both the reading and writing self-efficacy scales consist of skill and task subscales that may provide a different solution, especially since the respondents belong to an incarcerated population having varying reading and writing skills (Vacca, 2004). In addition, findings from educational research have revealed some inconsistency concerning self-efficacy for self-regulated learning as a distinct factor (Bong, 2001; Klassen \& Usher, 2010), which indicate a need for further examination.

Thus, to reveal a simple structure of all items of the academic self-efficacy instrument, a principal component analysis (PCA) for the extraction of factors with varimax (orthogonal) rotation was conducted on the 1,276 respondents. This procedure does not allow for correlated factors, which is in line with the primary theory on self-efficacy (Bandura, 2006).

Based on Kaiser's eigenvalue-greater-than-one criterion (K1) and scree plot (Cattell, 1988), five components explaining 73.1 percent of the variance were initially extracted from the component analysis. The percentage of variance explained and their eigenvalues for components 1 through 5 were 48.9 (19.57), 11.2 (4.46), 6.8 (2.72), 3.6 (1.42), and 2.7 (1.07), respectively. Component 1 included all writing skill and task items and the reading skill items, whereas component 5 included only the reading task items. Hence, it was difficult to interpret and label these two components. Components 2, 3, and 4 were easily interpreted as self-efficacy in mathematics, ICT, and self-regulated learning. However, a Monte Carlo Parallel Analysis (Watkins, 2000) was performed to verify the number of components to be retained. This method is found to show the least variability and sensitivity to different factors or components, compared to other extraction methods such as the scree test and K1 (Ledesma \& Valero-Mora, 2007). The parallel analysis yielded a solution of four components, as the fifth component did not reach a required eigenvalue of $>1.24$. Thus, the data were subjected to a forced four-component solution (see Table 1). The components were labeled: (1) Literacy self-efficacy, (2) Mathematics self-efficacy, (3) ICT self-efficacy, and (4) Self-efficacy for self-regulated learning. The literacy self-efficacy component included all reading task items that initially encompassed the fifth component, in addition to the reading skill items and all writing items. Based on sample size, a cut-off of 0.40 was used to identify significant factor loadings (Hair, Anderson, Tatham, \& Black, 1995). Items that cross-loaded (loaded $>0.4$ on more than one component and with a discrepancy of $<0.2$ between them) were omitted from further analyses (Ferguson \& Cox, 1993).

From the results, a few item cross-loadings met the removal criteria and were thus eliminated. This included one cross-loading between component 1 (literacy self-efficacy) and 2 (mathematics self-efficacy), and three cross-loadings between component 1 and 4 (self-efficacy for self-regulated learning) (see Table 1).

Subsequent to the component analysis, the retained item responses on each subscale were summarized and averaged into four subscale scores, each ranging from 0 to 10 with higher scores indicating stronger self-efficacy in the respective domains. Descriptives, correlations, and Cronbach's $\alpha$ coefficients for the subscales are reported in Table 2.

The results in Table 2 show the mean values on all self-efficacy subscales, with ICT self-efficacy as the highest score and mathematics self-efficacy as the lowest score. Internal consistency was satisfactory for all subscales. All correlations between them were significant and positive, and ranged from medium to large, according to Cohen's (1988) guidelines. 
Table 1

Principal Component Analysis of the Academic Self-Efficacy Scale. Four-component-solution. $(N=1154)$

\begin{tabular}{|c|c|c|c|c|c|}
\hline \multirow[b]{2}{*}{ Scale item } & \multicolumn{4}{|c|}{ Components } & \multirow[b]{2}{*}{$h^{2}$} \\
\hline & 1 & 2 & 3 & 4 & \\
\hline Write words correctly based on how they are pronounced & .73 & .27 & .19 & .27 & .72 \\
\hline Read newspaper & .71 & .12 & .15 & .08 & .54 \\
\hline Use words correctly in singular and plural & .70 & .36 & .16 & .26 & .71 \\
\hline Read textbooks & .67 & .21 & .17 & .30 & .61 \\
\hline Understand the main point in a story & .67 & .28 & .15 & .36 & .67 \\
\hline Read letters from someone I know & .66 & .06 & .21 & -.04 & .49 \\
\hline Read aloud correctly & .65 & .32 & .12 & .33 & .65 \\
\hline Include the most important points in written work & .65 & .34 & .17 & 42 & .74 \\
\hline Write letters to someone I know & .63 & .07 & .19 & .27 & .52 \\
\hline Understand the meaning of plural endings, prefixes and suffixes & .61 & .38 & .10 & .40 & .69 \\
\hline Understand the meaning of all words in a book & .61 & .36 & .12 & .39 & .66 \\
\hline Write a summary of a book you have read & .61 & .27 & .14 & .49 & .70 \\
\hline Write a story of something you have experienced & .60 & .17 & .20 & .38 & .58 \\
\hline Use correct punctuation & .60 & .35 & .20 & .36 & .65 \\
\hline Read novels & .58 & 19 & .09 & .29 & .47 \\
\hline Write down rules of a game & .55 & .30 & .19 & .42 & .60 \\
\hline Do sums using fractions & .22 & .85 & .14 & .23 & .85 \\
\hline Solve equations & .16 & .85 & .16 & .23 & .82 \\
\hline Do sums using percentages & .30 & .83 & .12 & .24 & .85 \\
\hline Work out the interest on a loan & .20 & .82 & .12 & .28 & .81 \\
\hline Present measurements in a diagram & .22 & .78 & .19 & .30 & .77 \\
\hline Work out the volume of a cube & .19 & .77 & .18 & .23 & .72 \\
\hline Do sums in which you have to multiply or divide & .40 & .75 & .10 & .20 & .77 \\
\hline Create a budget and keep accounts & .22 & .73 & .18 & .35 & .74 \\
\hline Do sums in which you have to add or subtract & .48 & .68 & .09 & .16 & .73 \\
\hline Send photos (or other documents) as attachments to an email & .16 & .13 & .90 & .10 & .86 \\
\hline Download or install a program on a computer & .08 & .09 & .88 & .04 & .79 \\
\hline Use a memory stick or CD in a computer & .16 & .12 & .87 & .04 & .80 \\
\hline Send and receive emails & 21 & .11 & .86 & .13 & .82 \\
\hline Use a chat program (internet chatting) & .13 & .04 & .85 & .04 & .74 \\
\hline Use a search engine (e.g. Google) to search for information & .26 & .09 & .80 & .12 & .73 \\
\hline Use a computer keyboard & 21 & .18 & .77 & .18 & .70 \\
\hline Use a spreadsheet on a computer & .14 & .40 & .67 & .16 & .66 \\
\hline Pull myself together, so that I get schoolwork done & .24 & .32 & .10 & .77 & .76 \\
\hline Concentrate on schoolwork in a classroom & .34 & .31 & .10 & .73 & .75 \\
\hline Make weekly plans for school work & .31 & .31 & .10 & .73 & .73 \\
\hline Take notes during class & .36 & .26 & .12 & .72 & .73 \\
\hline Remember the contents of textbooks and lessons & .34 & .34 & .10 & .71 & .75 \\
\hline Complete schoolwork on time & .36 & .33 & .12 & .68 & .71 \\
\hline Use the library to find what I need for schoolwork & .43 & .25 & .13 & .60 & .63 \\
\hline
\end{tabular}

Note. Varimax rotation. Italicized entries denote primary component loadings exceeding the 0.40 cut-off. Loadings in boldface indicate cross-loadings meeting removal criteria. Component $1=$ Literacy self-efficacy, Component $2=$ Mathematics self-efficacy, Component 3 = ICT self-efficacy, Component 4 = Self-efficacy for self-regulated learning.

$h^{2}=$ Communalities.

Table 2

Descriptives, Correlations, and Cronbach's a Coefficients for the Academic Self-Efficacy Subscales.

\begin{tabular}{|c|c|c|c|c|c|c|c|c|c|}
\hline & Subscale & $N$ & $M$ & $S D$ & $\alpha$ & (1) & (2) & (3) & (4) \\
\hline (1) & Literacy S-E & 1165 & 7.64 & 2.01 & .95 & 1.0 & & & \\
\hline (2) & Mathematics S-E & 1162 & 6.01 & 2.95 & .96 & $.66 * *$ & 1.0 & & \\
\hline (3) & ICT S-E & 1166 & 7.66 & 2.66 & .95 & $.45^{* *}$ & $.39 * *$ & 1.0 & \\
\hline (4) & $\begin{array}{l}\text { S-E for self-regulated } \\
\text { learning }\end{array}$ & 1168 & 6.60 & 2.53 & .93 & $.77 * *$ & $.68 * *$ & $.34 * *$ & 1.0 \\
\hline
\end{tabular}

Note. Variation in sample size is due to missing data. S-E = Self-efficacy.

$* * p<.01$.

Independent-samples t-tests were utilized to compare the academic self-efficacy scores for participants $(\mathrm{n}=683)$ and non-participants $(\mathrm{n}=592)$ in prison education. The analyses demonstrated statistically significant score differences in favor of participants in mathematics self-efficacy (participants $(M=6.43, S D=$ $2.85)$, non-participants $(M=5.65, S D=3.04), t(1096)=3.82, p=0.000$, in ICT self-efficacy (participants $(M$ $=7.80, S D=2.53)$, non-participants $(M=7.49, S D=2.80), t(1077)=1.93, p=0.054$, and in self-efficacy for self-regulated learning (participants $(M=6.94, S D=2.23)$, non-participants $(M=6.20, S D=2.79), t(1010)$ $=4.96, p=0.000$. However, according to Cohen's (1988) guidelines, small effect size estimates were found 


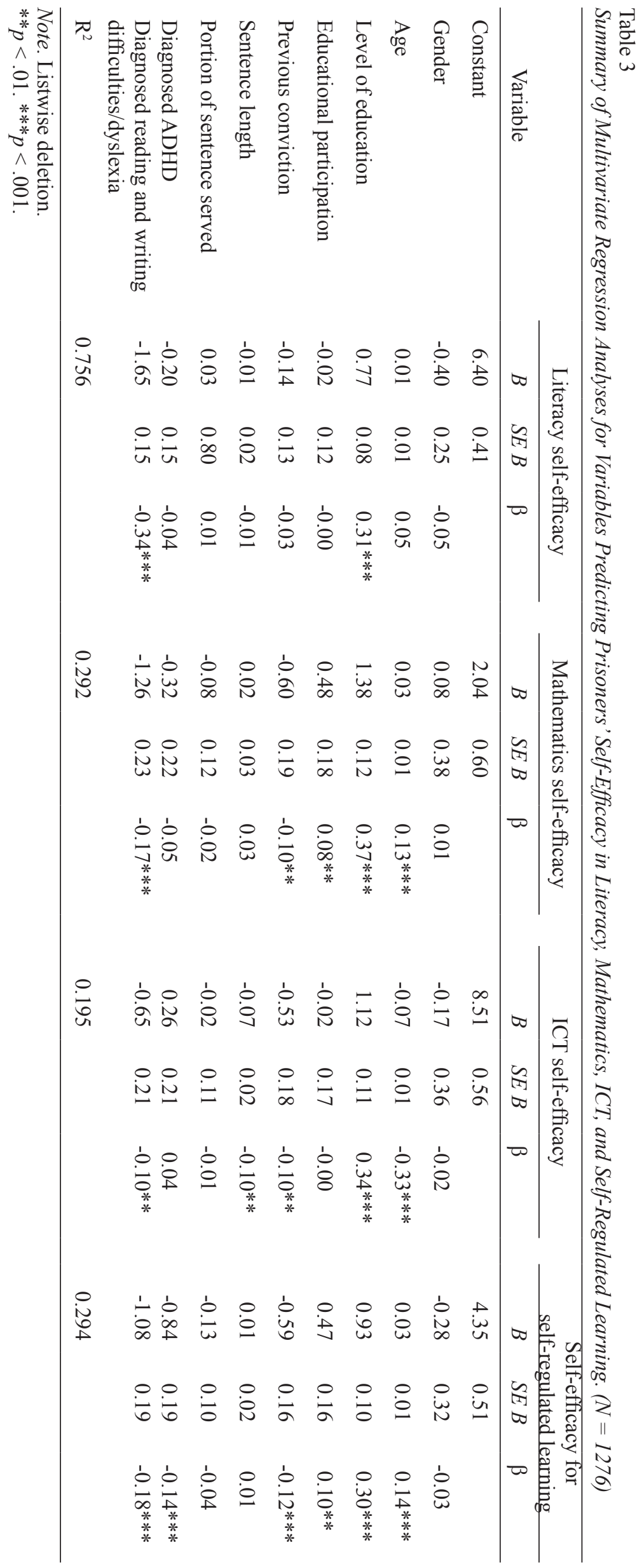


in all the above cases, ranging from $d=0.12$ to 0.31 . No statistically significant group mean differences were found in literacy self-efficacy.

In order to account for the influence of participation in prison education, previous convictions, sentence length, and portion of sentence served on the academic self-efficacy components, while controlling for other factors, four regression analyses were conducted. The self-efficacy components were entered as dependent variables in the separate analyses. Participation in prison education, previous convictions, sentence length, and portion of sentence served were entered as independent variables in each analysis. Both educational participation and previous convictions were given two values: (1) no and (2) yes. Sentence length was assigned 15 values (see section on Questionnaire). Portion of sentence served was collapsed and given three values: (1) shorter than one-third, (2) between one-third and two-thirds, and (3) over two-thirds. The following variables served as controls: Gender: (1) female and (2) male, age (a continuous variable), level of education: (1) no education, (2) primary/ lower secondary school, and 1 or 2 years of upper secondary school, (3) completed upper secondary school, or vocational education, (4) individual subjects or a degree course at a university or university college), diagnosed reading and writing difficulties/dyslexia: (1) no and (2) yes, and diagnosed ADHD: (1) no and (2) yes).

The regression results (Table 3) show the influence of each independent variable on the four self-efficacy components, with all other variables kept constant. The results revealed that educational participation had no statistically significant effect on the prisoners' self-efficacy in literacy. However, educational participants scored significantly higher on mathematics self-efficacy and self-efficacy for self-regulated learning than non-participants. In contrast to results from the independent-samples t-test, educational participants and non-participants did not differ significantly in scores on ICT self-efficacy. While previous convictions did not have any statistically significant impact on literacy self-efficacy, it appears to be significantly associated with self-efficacy in mathematics, self-regulated learning, and ICT. With no previous convictions, prisoners scored higher on these three components. Sentence length had a significant influence only on self-efficacy in ICT in which scores decrease with longer sentence length. Portion of sentence served was not significantly related to any of the self-efficacy components.

Of the control variables, age, level of education, and diagnosed reading and writing difficulties/dyslexia and ADHD were statistically significant in association with one to four of the self-efficacy components. With increasing age, the prisoners scored higher on self-efficacy in mathematics and self-regulated learning. In contrast, younger prisoners scored higher on ICT self-efficacy than older prisoners. Furthermore, with a higher educational level, prisoners scored higher on all four self-efficacy components. With respect to ADHD, prisoners with such diagnosis scored lower on self-efficacy for self-regulated learning. Lastly, the results showed that prisoners with diagnosed reading and writing difficulties/dyslexia scored lower on all self-efficacy components. Gender was not significantly related to any of the self-efficacy components.

\section{Discussion}

A number of studies show that academic self-efficacy is related to academic achievement (Komarraju \& Nadler, 2013), and among prisoners it is related to participation in education (Jones, 2012). In the current study, we adapted an academic self-efficacy scale based on several authors (Jones, 2012; Manger et al., 2009; Vold, 2007) and the present authors added several items relevant for the prison education context in line with Bandura's guidelines. Pursuant to retention criteria, four forced components were calculated in a varimax rotated principal component analysis of a 40-item academic self-efficacy questionnaire: 1) literacy self-efficacy, 2) mathematic self-efficacy, 3) ICT self-efficacy, and 4) self-efficacy for self-regulated learning. The latter involve goal-directed activities that students initiate, such as concentrating on schoolwork in the classroom, making plans for the week, and completing schoolwork on time.

In contrast to what was reported by Shell et al. (1995), the reading and writing items were all included in a literacy self-efficacy component. There may be several explanations for this. First, reading and spelling skills are found to be impaired in a large proportion of prisoners in Norway. Second, Norwegian is a language with shallow orthography but complex phoneme structure (Seymour, 2008), which may lead to an increased probability of compensated skills in adults with dyslexia, and this may result in a minor difference in the perception of reading skills and spelling skills. In addition, "writing impairments" in Norway are usually 
understood as "spelling problems". Such issues may result in a difference in the contrast between literacy tasks and skills compared to what has been found in English language samples (Georgiou, Parrila, \& Papadopoulos, 2008). Further, a high correlation was observed between self-efficacy in literacy and mathematics, suggesting that these domains share some common aspects. According to theory, there is a likelihood for covariation between efficacy beliefs in distinct domains that share similar sub-skills, or when development of skills in dissimilar domains are socially structured and acquired together, such as academic skills in the educational context (Bandura, 2006). "Commonality of sub-skills and covariation of development will yield generality" (Bandura, 1989, p. 732). Results from various studies lend support for cross-domain correlations in academic self-efficacy in the present study (e.g., Bong, 1998; Zimmerman, Bandura, \& Martinez-Pons, 1992). Moreover, efficacy beliefs for self-regulated learning appeared to be related to both literacy and mathematics self-efficacy. Although correlations do not make causality, the finding can be seen in light of Zimmerman et al. (1992), who found, through path analysis, that students' self-efficacy for self-regulated learning influenced their efficacy beliefs for mastering various academic subjects (e.g., mathematics, science, reading and writing), which in turn had an effect on academic achievement. Thus, along these lines, to achieve academically, students need not only efficacy-beliefs to perform, but also beliefs in their capability to apply adaptive learning strategies (Jöet, Usher, \& Bressoux, 2011). This may help clarifying the correlative processes between self-efficacy for self-regulated learning and efficacy beliefs in literacy and mathematics, as found in the present study.

Important variables considered in the study were educational participation, previous convictions, sentence length, and portion of sentence served. Initial t-test results revealed a difference between educational participants and non-participants with respect to academic self-efficacy in which participants had better outcomes in terms of efficacy beliefs in self-regulated learning, mathematics and ICT. Because self-efficacy judgements influence the choices people make (Pajares, 2003), the extent of academic self-efficacy may thus serve as a determinant for participation or non-participation in education. In line with this, non-participants may have refrained from educational activities due to initially lower academic self-efficacy than educational participants had. Alternatively, prisoners may have developed a stronger sense of self-efficacy in various academic areas during participation, such as self-regulated learning and mathematics. Both assumptions are probably relevant, as academic self-efficacy may be both a determinant for enrolment and an effect of participation. The differences between participants and non-participants were small, however, in terms of Cohen's effect size measures. In addition, no significant difference was found between participants and non-participants in literacy self-efficacy. Other studies (Eikeland et al., 2009; Jones et al., 2012) among incarcerated individuals have reported no association between self-reported reading skills and participation in prison education. This may indicate that previously educationally disadvantaged prisoners see both new opportunities and different standards of comparison than outside prison. Behind bars, they can undoubtedly compare themselves with individuals who have similar learning problems, which is in line with "the frame of reference hypothesis" (Marsh \& Parker, 1984).

We used multivariate linear regressions to study how participation in education, previous convictions, sentence length, and portion of sentence served may predict academic self-efficacy. In the analyses, we controlled for commonly used background variables that could influence such beliefs (gender, age, educational level, ADHD, reading and writing difficulties/dyslexia). Participation in education had a positive influence on self-efficacy in both mathematics and self-regulated learning. However, in contrast to the initial t-test result, the effect of participation in education on ICT self-efficacy disappeared after controlling for relevant variables related to academic self-efficacy. Participation in education together with previous convictions, sentence length, and portion of sentence served did not influence prisoners' literacy self-efficacy.

A possible explanation of the non-significant effect of participation in education on ICT self-efficacy may be prisoners' inadequate access to ICT equipment, whether they participate in prison education or not. A shortage of ICT equipment was stated as the major cause of problems related to the educational activities by prisoners in all five Nordic countries (Eikeland et al., 2009). Alternatively, the prisoners' fairly high mean score on ICT self-efficacy may have created a ceiling effect which reduces the chance for a significant difference between participants and non-participants, or we may need measuring items requiring a higher capability level to distinguish between different categories of participants. Participants who reported no previous convictions scored higher on self-efficacy in mathematics, ICT and self-regulated learning. One may speculate 
that individuals who have previously been convicted may have more complex problems, including drug abuse, lower socio-economic status and lower education than first-time convicted individuals. For ICT self-efficacy, a possible explanation may be that prisoners without previous convictions have been exposed to the latest developments in ICT to a larger degree than recidivists. Further, the results showed that the prisoners' sentence length influences their ICT self-efficacy in which perceived efficacy increased with shorter sentence length. The explanation may be that while in prison, individuals have limited access to ICT, which may have adverse effects on the prisoners' ICT self-efficacy as it limits their opportunity for authentic mastery experiences within this area. Based on a tenable inference that prisoners serving longer sentences on average have spent more time in prison than prisoners with shorter sentences, a reasonable presumption is that long-term prisoners are more prone to report lower self-efficacy as a resulting consequence of inadequate training of ICT skills. A study by Poelmans, Truyen, and Stockman (2012) of 195 students in higher education found a significant correlation between the students' global ICT skills and computer self-efficacy, indicating the importance of proper training. The prisoners were asked how much of their sentence they had served so far, but the portion of sentence served was not significantly related to any of the self-efficacy components.

Age, level of education, diagnosed reading and writing difficulties/dyslexia, and ADHD were significantly associated with one to three of the self-efficacy components. The prisoners scored higher on self-efficacy in mathematics and self-regulated learning with increasing age. One possible explanation is that with increasing distance from former schooling, their efficacy beliefs will be less affected. A positive relationship between age and academic self-efficacy among prisoners was also reported by Jones et al. (2013). In contrast, younger prisoners scored higher on ICT self-efficacy than older prisoners. A plausible explanation is that younger prisoners have had better access to computer technology from childhood, in school and outside school, than older prisoners. Further, with higher educational level, the prisoners scored higher on mathematics self-efficacy, ICT self-efficacy and self-efficacy for self-regulated learning. Such findings are in line with former studies which show that academic self-efficacy is significantly and directly related to academic performance and educational level (Chemers, Hu, \& Garcia, 2001; Jones, 2012). Several studies show that ADHD has a negative impact on education and employment (Barkley, Fischer, Smallish, \& Fletcher, 2006; Mannuzza, Klein, Bessler, Malloy, \& Hynes, 1997). This may reduce the opportunities for mastery experiences and thus have a negative influence on academic self-efficacy. However, prisoners with such diagnosis did not score lower on the self-efficacy components other than self-efficacy for self-regulated learning. The results also showed that prisoners with diagnosed reading and writing difficulties/dyslexia scored lower on all self-efficacy components, which is in line with similar studies in the prison population (Jones, 2012). Contrary to this, there is some evidence that students with learning difficulties overestimate their writing self-efficacy but not their mathematics self-efficacy (Klassen, 2002).

Gender was not significantly related to any of the self-efficacy components among the prisoners. In comparison, a recent meta-analysis of students in general identified an overall effect size of 0.08 , favoring males, which is a small difference according to Cohen's guidelines. However, females exhibited higher language self-efficacy than males, while males displayed higher mathematics and computer self-efficacy than females (Huang, 2013)

\section{Limitations of the study}

Despite the study's contribution to the prison education literature, it has several limitations. For some of the variables, we relied on retrospective self-reports, and there were no sources of corroborative information such as official records on educational background and sentence length. It is known that when asked to rate their weaknesses in questionnaires, respondents tend to underestimate (Olsen, 2001; Samuelsson, Gustavsson, Herkner, \& Lundberg, 2000). Prisoners' academic self-efficacy was also analyzed via self-reported data, which were not compared to their actual mastery of tasks in literacy, mathematics, ICT or self-regulated learning. Overall, the prisoners in the current study rated their academic self-efficacy as moderate to high. One would assume that many prisoners hold low academic efficacy beliefs, partly due to the history of poor mastery experiences in school. However, according to research findings, some individuals generally tend to overrate their academic self-efficacy (Bandura, 1997; Pajares, 1996), and this was confirmed in Klassen's (2002) review of the literature on the self-efficacy beliefs of students with learning difficulties. Earlier in the 
discussion, we referred to the frame of reference hypothesis (Marsh \& Parker, 1984). The hypothesis is based on the assumptions that individuals compare their own academic abilities with the abilities of other individuals within their reference group and use this relativistic impression as a basis for forming their self-concept. According to Bandura (1997), self-concept, which is a composite view of oneself, largely reflects people's beliefs in their personal efficacy. Although we have data on prisoners' current participation in education, we lack data on a variety of sources, such as prior and present mastery experiences that may contribute to the prediction of academic self-efficacy in a prison context. We recommend that future studies address these limitations. Also, we lack good studies on how prisoners' academic self-efficacy can be enhanced. Although academic self-efficacy is theorized to be improved in any context by providing learners with mastery experiences, role models, social or verbal persuasion, and a classroom climate that does not make them anxious or worried, the lack of studies in a prison learning environment calls for further examination.

\section{Practical implications}

Previous studies (e.g., Davis et al., 2013; Kim \& Clark, 2013) have shown that prison education reduces recidivism. Although we do not have similar studies on the relationship between participation in prison education and recidivism in Norway, a positive relationship between academic self-efficacy and achievement in school has been revealed (Dinther et al., 2011; Pajares, 1996; Zimmerman, 2000). Academic self-efficacy is essential to academic success. It sustains motivation and promotes learning. Apparently, academic self-efficacy may be of indirect importance for post-release success and consequently lower recidivism. Based on the research they have reviewed, Linnenbrink and Pintrich (2003) recommend that teachers should help students maintain relatively high but accurate self-efficacy, provide them with challenging academic tasks that they can achieve with effort, foster the belief that competence or ability is changeable, and finally promote their domain-specific self-efficacy beliefs rather than global self-esteem. Self-efficacy is increased when students adopt short-term goals, are taught to use specific learning strategies, and receive rewards based on achievement, not just engagement, because achievement rewards signal increasing competence (Graham \& Weiner, 1996). Thus, an important pedagogical implication emerging from the findings is that prison staff should take seriously their share of the responsibility in enhancing the academic self-efficacy of the prisoners. In particular, prisoners with prior convictions who have a lower level of education and do not participate in prison education need to be empowered with resources that can boost their self-efficacy. Although the mean ICT self-efficacy score was in the higher range, the findings may indicate that inadequate equipment puts prisoners at a competitive disadvantage after release and that the prison authorities must quickly solve the discrepancy between prison security routines and the need of prisoners involved in educational activities to use ICT equipment in their studies. The period of incarceration is an opportunity for prison teachers to take steps to improve prisoners' academic self-efficacy, including their ICT self-efficacy, and especially the self-efficacy of prisoners who have learning challenges due to ADHD and reading and writing difficulties. Better education will likely contribute towards improving the prospect for successful reintegration into the society. Also, prison staff and prison educators should be aware that prisoners' academic self-efficacy may serve as an important guiding factor for their own decision to enroll in education or not. Thus, assessment of academic self-efficacy can provide important guidelines for educational staffs' academic supervision in a prison context.

In spite of its limitations, the present study has important implications for further research and for prison education in practice. It shows that participation in educational activities has an influence on prisoners' academic self-efficacy. In addition, the prison staff and the prison educators should be aware of the aspects of the sentence that can affect prisoners' self-efficacy and thus their learning and future return to a life without crime. The results have particular implications for the planning of learning activities that can promote mastery experiences in all areas of academic skills, including learning activities for prisoners with previous convictions and low education.

\section{References}

Allred, S. L., Harrison, L. D., \& O’Connell, D. J. (2013). Self-efficacy: An important aspect of prison-based learning. The Prison Journal, 93, 211-233. doi:10.1177/0032885512472964

Asbjørnsen, A., Eikeland, O.-J., \& Manger, T. (2015). Symptoms of ADHD are related to education and work experience among incarcerated adults. Journal of Prison Education and Reentry, 2(1), 3-15. 
http://dx.doi.org/10.15845/jper.v2i1.702

Bandura, A. (1986). Social foundations of thought and action: A social cognitive theory. Englewood Cliffs, NJ: Prentice-Hall.

Bandura, A. (1989). Regulation of cognitive processes through perceived self-efficacy. Developmental Psychology, 25, 729-735. http://dx.doi.org/10.1037/0012-1649.25.5.729

Bandura, A. (1997). Self-efficacy: The exercise of control. New York: W. H. Freeman \& Co.

Bandura, A. (2006). Guide for constructing self-efficacy scales. In F. Pajares \& T. Urdan (Eds.), Self-efficacy beliefs of adolescents (pp. 307-337). Greenwich, CT: Information Age Publishing.

Barkley, R. A., Fischer, M., Smallish, L., \& Fletcher, K. (2006). Young adult outcome of hyperactive children: Adaptive functioning in major life activities. Journal of the American Academy of Child \& Adolescent Psychiatry, 45, 192-202. http://dx.doi.org/10.1097/01.chi.0000189134.97436.e2

Bong, M. (1998). Tests of the internal/external frames of reference model with subject-specific academic self-efficacy and frame-specific academic self-concepts. Journal of Educational Psychology, 90, 102-110. http://dx.doi.org/10.1037/0022-0663.90.1.102

Bong, M. (2001). Role of self-efficacy and task-value in predicting college students' course performance and future enrollment intentions. Contemporary Educational Psychology, 26, 553-570. doi:10.1006/ ceps. 2000.1048

Bong, M., \& Skaalvik, E. M. (2003). Academic self-concept and self-efficacy: How different are they really? Educational Psychology Review, 15, 1-40. doi:10.1023/A:1021302408382

Cattell, R. B. (1988). The meaning and strategic use of factor analysis. In J. R. Nesselroade \& R. B. Cattell (Eds.), Handbook of multivariate experimental psychology (2nd ed., pp. 131-203). New York: Plenum.

Chemers, M. M., Hu, L.-t., \& Garcia, B. F. (2001). Academic self-efficacy and first-year college student performance and adjustment. Journal of Educational Psychology, 93, 55-64. doi:10.1037//00220663.93.1.55

Christie, N. (1970). Modeller for fengselsorganisasjonen [Prison organization models]. In R. Østensen (Ed.), I stedet for fengsel (pp. 70-78). Oslo: Pax.

Cohen, J. (1988). Statistical power analysis for the behavioral sciences (2nd ed.). New York: Academic Press.

Council of Europe. (1990). Education in prison. Recommendation No. R (89) 12 adopted by the Committee of Ministers of the Council of Europe on 13 October 1989 and explanatory memorandum. Retrieved May 29, 2013, from http://www.epeamalta.org/uploads/3/0/6/4/3064611/education in_prison.pdf

Council of Europe. (2006). Recommendation Rec(2006)2 of the Committee of Ministers to member states on the European Prison Rules. Retrieved May 29, 2013, from https://search.coe.int/cm/Pages/ result_details.aspx?ObjectID $=09000016805 \mathrm{~d} 8 \mathrm{~d} 25$

County Governor of Hordaland. (2005). Researched-based evaluation of education in Norwegian prisons. Recommendations from a group nominated to monitor the evaluation of education in Norwegian prisons. Bergen: County Governor of Hordaland.

Davis, L. M., Bozick, R., Steele, J. L., Saunders, J., \& Miles, J. N. V. (2013). Evaluating the effectiveness of correctional education. A meta-analysis of programs that provide education to incarcerated adults. Retrieved November 02, 2013, from http://www.rand.org/content/dam/rand/pubs/ research_reports/RR200/RR266/RAND_RR266.pdf

Dhami, M. K., Ayton, P., \& Loewenstein, G. (2007). Adaptation to imprisonment: Indigenous or imported? Criminal Justice and Behavior, 34, 1085-1100. doi:10.1177/0032885512472964

Dinther, M. v., Dochy, F., \& Segers, M. (2011). Factors affecting students' self-efficacy in higher education. Educational Research Review, 6, 95-108. doi:10.1016/j.edurev.2010.10.003

Eikeland, O.-J., Manger, T., \& Asbjørnsen, A. (2009). Education in Nordic prisons: Prisoners' educational backgrounds, preferences and motivation. (TemaNord 2009:508). Copenhagen: Nordic Council of Ministers.

Eikeland, O.-J., Manger, T., \& Asbjørnsen, A. (2013). Nordmenn i fengsel: Utdanning, arbeid og kompetanse [Norwegians in prison: Education, work, and competence]. (Report 3:13). Bergen: Fylkesman- 
nen i Hordaland.

European Commission. (2011). Prison education and training in Europe: A review and commentary of existing literature, analysis and evaluation. Retrieved August 15, 2013, from http://ec.europa.eu/ justice/news/consulting_public/0012/Fullreport_en.pdf

Ferguson, E., \& Cox, T. (1993). Exploratory factor analysis: A users' guide. International Journal of Selection and Assessment, 1, 84-94. doi:10.1111/j.1468-2389.1993.tb00092.x

Georgiou, G. K., Parrila, R., \& Papadopoulos, T. C. (2008). Predictors of word decoding and reading fluency across languages varying in orthographic consistency. Journal of Educational Psychology, 100, 566-580. http://dx.doi.org/10.1037/0022-0663.100.3.566

Graham, S., \& Weiner, B. (1996). Theories and principles of motivation. In D. C. Berliner \& R. C. Calfee (Eds.), Handbook of educational psychology (pp. 63-48). New York: MacMillan.

Hair, J. F., Jr., Anderson, R. E., Tatham, R. L., \& Black, W. C. (1995). Multivariate data analysis with readings. Englewood Cliffs, NJ: Prentice Hall.

Huang, C. (2013). Gender differences in academic self-efficacy: A meta-analysis. European Journal of Psychology of Education, 28, 1-35. doi:10.1007/s10212-011-0097-y

Jackson, K. L., \& Innes, C. A. (2000). Affective predictors of voluntary inmate program participation. Journal of Offender Rehabilitation, 30(3-4), 1-19. http://dx.doi.org/10.1300/J076v30n03_01

Jones, L. Ø. (2012). Effects of reading skills, spelling skills and accompanying efficacy beliefs on participation in education. A study in Norwegian prisons. Doctoral dissertation, University of Bergen.

Jones, L. Ø., Manger, T., Eikeland, O.-J., \& Asbjørnsen, A. (2013). Participation in prison education: Is it a question of reading and writing self-efficacy rather than actual skills? Journal of Correctional Education, 64, 41-62. Retrieved October 14, 2014, from https://www.ncjrs.gov/App/Publications/abstract.aspx?ID $=265463$

Jones, L. Ø., Varberg, J., Manger, T., Eikeland, O.-J., \& Asbjørnsen, A. (2012). Reading and writing self-efficacy of incarcerated adults. Learning and Individual Differences, 22, 343-349. doi:10.1016/j. lindif.2012.01.008

Jöet, G., Usher, E. L., \& Bressoux, P. (2011). Sources of self-efficacy: An investigation of elementary school students in France. Journal of Educational Psychology, 103, 649-663. http://dx.doi.org/10.1037/ a0024048

Kim, R. H., \& Clark, D. (2013). The effect of prison-based college education programs on recidivism: Propensity score mathcing approach. Journal of Criminal Justice, 41, 196-204. http://dx.doi. org/10.1016/j.jcrimjus.2013.03.001

Klassen, R. (2002). A question of calibration: A review of the self-efficacy beliefs of students with learning disabilities. Learning Disabilities Quarterly, 25, 88-102. doi:10.2307/1511276

Klassen, R., \& Usher, E. L. (2010). Self-efficacy in educational settings: Recent research and emerging directions. In T. C. Urdan \& S. A. Karabenick (Eds.), Advances in motivation and achievement. The decade ahead: Theoretical perspectives on motivation and achievement (pp. 1-33). Bingley, UK: Emerald Publishing Group.

Komarraju, M., \& Nadler, D. (2013). Self-efficacy and academic achievement: Why do implicit beliefs, goals, and effort regulation matter? Learning and Individual Differences, 15, 67-72. doi:10.1016/j. lindif.2013.01.005

LaRose, R., Gregg, J. L., Strover, S., Straubhaar, J., \& Carpenter, S. (2007). Closing the rural broadband gap: Promoting adoption of the Internet in rural America. Telecommunications Policy, 31, 359-373. doi:10.1016/j.telpol.2007.04.004

Ledesma, R. D., \& Valero-Mora, P. (2007). Determining the number of factors to retain in EFA: An easyto-use computer program for carrying out parallell analysis. Practical Assessment, Research \& Evaluation, 12(2), 1-11. Retrieved April 23, 2013, from http://www.pareonline.net/getvn. asp? $\mathrm{v}=12 \& \mathrm{n}=2$

Linnenbrink, E. A., \& Pintrich, P. R. (2003). The role of self-efficacy beliefs in student engagement and learning in the classroom. Reading \& Writing Quarterly: Overcoming Learning Difficulties, 19, 119-137. doi:10.1080/10573560308223

Lochner, L., \& Moretti, E. (2004). The effect of education on crime: Evidence from prison inmates, arrests, and 
guage: Does it test language ability, or computer competence? A web-based measure of English reading and ICT competence. Nordic Journal of Digital Literacy, 4, 143-158. Retrieved June 14, 2015, from https://www.idunn.no/dk/2009/03-04/art02

Mannuzza, S., Klein, R. G., Bessler, A., Malloy, P., \& Hynes, M. E. (1997). Educational and occupational outcome of hyperactive boys grown up. Journal of the American Academy of Child \& Adolescent Psychiatry, 36, 1222-1227. doi:10.1097/00004583-199709000-00014

Marsh, H. W., \& Parker, J. W. (1984). Determinants of student self-concept: Is it better to be a relatively large fish in a small pond even if you don't learn to swim as well? Journal of Personality and Social Psychology, 47, 213-231. http://dx.doi.org/10.1037/0022-3514.47.1.213

Nally, J. M., Lockwood, S., Ho, T., \& Knutson, K. (2014). Post-release recividism and employment among different types of released offenders: A 5-year follow-up study in the United States. International Journal of Criminal Justice Sciences, 9, 16-34. Retrieved October 17, 2015, from http:// www.sascv.org/ijcjs/pdfs/nallyetalijcjs2014vol9issue1.pdf

Olsen, H. (2001). Sprogforståelse og hukommelse i danske surveyundersøkelser [Language understanding and memory in Danish surveys]. (Report 1:15). Retrieved August 03, 2015, from https://pure.sfi. dk/ws/files/326602/0115_Sprogforstaaelse_bind_I.pdf

Pajares, F. (1996). Self-efficacy beliefs in academic settings. Review of Educational Research, 66, 543-578. doi:10.3102/00346543066004543

Pajares, F. (2002). Gender and perceived self-efficacy in self-regulated learning. Theory Into Practice, 41, 116-125. http://dx.doi.org/10.1207/s15430421tip4102_8

Pajares, F. (2003). Self-efficacy beliefs, motivation, and achievement in writing: A review of the literature. Reading \& Writing Quarterly: Overcoming Learning Difficulties, 19, 139-158. http://dx.doi. org/10.1080/10573560308222

Palmer, S. M. (2012). Postsecondary correctional education. Recognizing and overcoming barriers to success. Adult Learning, 23, 4163-4169. doi:10.1177/1045159512457918

Poelmans, S., Truyen, F., \& Stockman, C. (2012). ICT skills and computer self-efficacy of higher education. Paper presented at the INTED2012 Conference 5th-7th MarchValencia, Spain. Retrieved May 07, 2015, from https://irias.kuleuven.be/bitstream/123456789/341696/1/1303.pdf

Rose, K., \& Rose, C. (2014). Enrolling in college while in prison: Factors that promote male and female prisoners to participate. Journal of Correctional Education, 65, 20-39. Retrieved September 03, 2016, from http://search.proquest.com/docview/1538272337?accountid=8579

Ross, J. (2009). Education from the inside, out: The multiple benefits of college programs in prison. Retrieved April 21, 2015, from http://www.correctionalassociation.org/wp-content/uploads/2012/05/ Higher_Education_Full_Report_2009.pdf

Roth, B. B., \& Manger, T. (2014). The relationship between prisoners' educational motives and previous incarceration, sentence length, and sentence served. London Review of Education, 12, 209-220. Retrieved July 15, 2014, from http://link.springer.com/article/10.1007/s10610-012-9187-x

Samuelsson, S., Gustavsson, A., Herkner, B., \& Lundberg, I. (2000). Is the frequency of dyslexic problems among prison inmates higher than in a normal population? Reading and Writing, 13, 297-312. doi:10.1023/A:1026434631998

Schunk, D. H., \& Meece, J. L. (2006). Self-efficacy development in adolescence. In F. Pajares \& T. Urdan (Eds.), Self-efficacy beliefs of adolescents (pp. 71-96). Greenwich, CT: Information Age Publishing.

Schunk, D. H., \& Mullen, C. A. (2012). Self-efficacy as an engaged learner. In S. L. Christenson, A. L. Reschly, \& C. Wylie (Eds.), Handbook of research on student engagement (pp. 219-235). New York: Springer.

Schunk, D. H., \& Pajares, F. (2002). The development of academic self-efficacy. In A. Wigfield \& J. S. Eccles (Eds.), Development of achievement motivation (pp. 15-31). San Diego: Academic Press.

Seymour, P. H. K. (2008). Continuity and discontinuity in the development of single-word reading: Theoretical speculations. In E. L. Grigorenko \& A. J. Naples (Eds.), Single-word reading: Behavioral and biological perspectives (pp. 1-24). New York: Lawrence Erdbaum Associates.

Shell, D. F., Colvin, C., \& Bruning, R. H. (1995). Self-efficacy, attribution, and outcome expectancy mech- 
anisms in reading and writing achievement: Grade-level and achievement-level differences. Journal of Educational Psychology, 87, 386-398. doi:10.1037/0022-0663.87.3.386

Statistics Norway. (June 18, 2013). Befolkningens utdanningsnivå, 1. oktober 2012 [Population education level, October 1, 2012]. Retrieved August 16, 2015, from http://ssb.no/utdanning/statistikker/ utniv/aar/2013-06-18

The Education Act. Act of 17 July 1998 no. 61 relating to primary and secondary education and training.

Vacca, J. S. (2004). Educated prisoners are less likely to return to prison. Journal of Correctional Education, 55, 297-305. Retrieved June 06, 2013, from http://www.jstor.org/stable/23292095

Vold, V. (2007). Age-related development aspects in technological interface design. Unpublished doctoral dissertation, University of Bergen.

Watkins, M. W. (2000). Monte carlo PCA for parallel analysis [computer software]. State College, PA: Ed \& Psych Associates.

Zimmerman, B. J. (2000). Self-efficacy: An essential motive to learn. Contemporary Educational Psychology, 25, 82-91. doi:10.1006/ceps.1999.1016

Zimmerman, B. J., Bandura, A., \& Martinez-Pons, M. (1992). Self-motivation for academic attainment: The role of self-efficacy beliefs and personal goal setting. American Educational Research Journal, 29, 663-676. doi:10.3102/00028312029003663

\section{Acknowledgements and funding}

The study was initiated and supported by the County Governor of Hordaland, the Department of Education, Norway. We would like to thank senior adviser Paal Christian Breivik and his colleagues at the County Governor's office, the headmasters of the prison schools and the prison governors, who organized the data collection. We also want to thank the prisoners who participated. We were totally dependent on your participation and collaboration to carry out this research.

Beate Buanes Roth is a PhD candidate. She is doing research on prisoners' educational motives and self-efficacy for schoolwork.

Arve Asbjørnsen is the Professor of Logopedics, at the University of Bergen and leader of the Bergen Cognition and Learning Group. His research interests includes learning disabilities, in particular cognitive challenges appearing with reading problems and ADHD. His reaserch also includes language acquouisition, bilingualism and cognitive impairments in psychiatric disorders like PTSD, schizophrenia and major depression, in addition to basic auditory measurements and auditory attention.

Terje Manger is a Professor in Educational Psychology at the Faculty of Psychology, the University of Bergen, Norway, and a member of the Bergen Cognition and Learning Group. He has published books and journal articles on topics such as general educational psychology, gender differences in mathematical achievement, motivation, self-concept and behaviour problems in school. 